\title{
Stability of economy of the organizations under the conditions of modern economic environment
}

\author{
Y. V. Lebedeva ${ }^{1}$, A.A. Sigankov ${ }^{2}$, O. N. Beketova ${ }^{2}$, I.V. Shatskaya ${ }^{2}$, and A.L. Frolov ${ }^{2}$ \\ ${ }^{1}$ Moscow Academy of Finance and Law (MFUA) \\ ${ }^{2}$ MIREA - Russian technological university, Prospekt Vernadskogo, 78, 119454 Moscow, Russia
}

\begin{abstract}
The article is devoted to the author's approach to the formation of indicators of the sustainability of the economy of organizations. The developed approach holds the attention focused on its classical understanding, modified for the modern entrepreneurial era, based on the environment of organizations' activities, a term of internal (interpolation) and external (extrapolation) factors that form their costs, determine the financial result and its efficiency, on which the prospective financial benefit. The study considered the selected resulting and factor indicators of the sustainability of the economy of organizations: the efficiency and cost of activities, changes in their results and costs under the influence of qualitative (profitability, profitability, expense) and quantitative (income, profit, costs) parameters of activity in dynamics. The construction of these dependencies between the selected combination of the resulting and factor indicators of the stability of the economy of organizations is carried out through the union of differentiated by types of additive, multiplicative and multiple interactions of intermediate (factor) values with the final (resulting) values. The combination of all types of dependencies that form a common system of the studied indicators will provide organizations with an accurate assessment of the analyzed final values and ranking pursuant to the degree of significance of the values of the intermediate group and the adoption of objective measures to optimize the sustainability of their economies. The material will benefit entrepreneurs of all spheres and industries, carrying out their activities under the current economic mechanism, education and science workers, students in economic areas.
\end{abstract}

\section{Introduction}

The economic environment that has developed at the present stage of human development is a complex market process that significantly affects the potential and competitiveness of business entities involved in the creation of material and intangible benefits. Its conditions are distinguished by a large representativeness of elements, without taking into account and analyzing which they are not able to function optimumly and be resistant to changes in the long and even current perspective. Therefore, they need not only to know what components it contains, but also to be able to assess how effective and intensive adaptation actions are and bring financial benefits. The above indicates the importance of methods for assessing 
indicators of economic sustainability for business entities. They are especially significant for organizations that incur much more costs than individual entrepreneurs due to larger projects, and the research topic is devoted precisely to the issue of forming a list of them in relation to the current economic mechanism.

The purpose of the study is aimed at constructing methods for calculating indicators, pursuant to which organizations may objectively calculate and assess the stability of their economy to the economic conjuncture (environment of activity) in its modern manifestation and subsequently identify the degree of influence on it of the corresponding factor indicators. Achieving this goal is feasible when solving several research tasks:

1. To reveal the environment of functioning of the economy of organizations in the modern conditions of doing business.

2. Compilation of a list of groups of economic costs, focusing on the environment of functioning of the economy of organizations.

3. Consolidation of groups of economic costs into a single nomenclature, comparison with them of the economic result in the general system of interrelation of the resulting and factor indicators of the sustainability of the economy of organizations, pursuant to the environment of its functioning.

The formulated tasks are solved using the studied scientific materials, methods and techniques that are most suitable for researching the selected topic.

\section{Materials and methods}

Information sources were the works of researchers who devoted their publications to the issues of economic sustainability of organizations in the current environment of their functioning. These include O.I. Averina [1], V. Andreev [2], Zh.O. Imashova [3], M.A. Kovtun [4], A.S. Krasnikova [5], E.A. Laskovskaya [6], S.N. Nechaeva [7], K.V. Pavlov [8], V.A. Rogov [9], T.M. Rogulenko [10], B.N. Khosiev [11], whose ideas contain prerequisites for the formation of indicators of stability of economy of organizations to the conditions of the modern economic environment.

The research being carried out is based on the computational and constructive method, which combines in the process of forming methods an additive, multiplicative and multiple combination of dependencies between the resulting and factor indicators of the sustainability of the economy of organizations. Such an approach to it is required for the complexity and consistency of the analysis of changes in results and costs, which are the basic measure for assessing the economic sustainability of organizations (successful functioning in modern conditions of the business environment), in conjunction with elements of statistical analysis that complement the process of detailing the dependence of the resulting and factor indicators under study.

Assessing the indicators of the sustainability of their economy, organizations using the selected methods will receive up-to-date and scrupulous information about the influence of factor indicators on the resulting indicators in general and in particular (for individual components of the functioning environment), which, in turn, affect the result and costs (fundamental factors of efficiency and competitiveness).

\section{Results and discussion}

For the formation of indicators, let us consider in more detail the interpolation and extrapolation factors of the environment of the functioning of the economy of organizations. The first (interpolation) group of factors includes the conditions for equipping with resources (personnel, assets and liabilities, natural objects), technologies (in production, sales, 
infrastructure, management). The second (extrapolation) group of factors is subdivided into two subgroups: direct, meaning the microenvironment (the presence of clients, partners, competitors, criminal structures, media, public organizations and movements), and indirect, which is a macroenvironment (economic, social, political, spiritual structures). Both groups of the environment for the functioning of organizations require from them the corresponding costs, consisting of the following groups of costs:

1. Interpolation costs (costs in the internal environment of the functioning of organizations caused by the costs of attracting, maintaining, operating resources, development, implementation, application of technologies).

2. Direct extrapolation costs (costs in the external environment caused by the costs of attracting and retaining customers, partners, conducting a legal fight against competitors, criminal structures, access to the media, interaction with public organizations and movements).

3. Indirect extrapolation costs (costs in the external environment caused by the costs of adaptation to periodic changes in the spheres of society, due to the change of economic eras).

Interpolation costs determine the opportunities, and extrapolation costs - the limitations of organizations in resisting the current economic environment and together form their potential, which must be fully realized in order to achieve maximum economic sustainability, manifested in the efficiency and cost of funds (sustainability efficiency) and their impact on changing the result and costs activity (intensification of sustainability), pursuant to the considered structure of modern internal and external costs.

Using these postulates, we will form indicators of the efficiency of the sustainability of the economy of organizations (formulas (1), (2), (3), (4)):

$$
\mathrm{PT}_{\text {эо(д) }}=\frac{\text { СД }_{\text {о }}}{\mathrm{P}_{\text {ои }}+\mathrm{P}_{\text {оэп }}+\mathrm{P}_{\text {оэк }}} \text {, }
$$

where $\mathrm{PT}_{\text {эо(д) }}$ - the aggregate performance of the sustainability of the economy of organizations in terms of income;

СД - aggregate income of organizations, RUR;

$\mathrm{P}_{\text {ои }}$ - interpolation costs of organizations to ensure economic sustainability, RUR;

$\mathrm{P}_{\text {оэп }}$ - direct extrapolation costs of organizations to ensure economic sustainability, RUR; RUR;

$\mathrm{P}_{\text {оэк }}$ - indirect extrapolation costs of organizations to ensure economic sustainability,

$$
\mathrm{PT}_{\text {эо(п) }}=\frac{\mathrm{C \Pi}_{\text {о }}}{\mathrm{P}_{\text {ои }}+\mathrm{P}_{\text {оэп }}+\mathrm{P}_{\text {оэк }}},
$$

where $\mathrm{PT}_{\text {эо(п) }}$ - the cumulative efficiency of the sustainability of the economy of organizations in terms of profit;

$\mathrm{C}_{\mathrm{o}}$ - aggregate profit of organizations, RUR;

$\mathrm{P}_{\text {ои }}$ - interpolation costs of organizations to ensure economic sustainability, RUR;

$\mathrm{P}_{\text {оэп }}$ - direct extrapolation costs of organizations to ensure economic sustainability, RUR; RUR;

$\mathrm{P}_{\text {оэк }}$ - indirect extrapolation costs of organizations to ensure economic sustainability,

$$
3 \mathrm{~T}_{\text {эо(д) }}=\frac{\mathrm{P}_{\text {ои }}+\mathrm{P}_{\text {оэп }}+\mathrm{P}_{\text {оэк }}}{\mathrm{CД}_{\mathrm{o}}},
$$

where $3 \mathrm{~T}_{\text {эо(д) }}$ - the total cost of the sustainability of the economy of organizations in terms of income;

$\mathrm{P}_{\text {ои }}$ - interpolation costs of organizations to ensure economic sustainability, RUR;

$\mathrm{P}_{\text {оэп }}$ - direct extrapolation costs of organizations to ensure economic sustainability, RUR; 
$\mathrm{P}_{\text {оэк }}$ - indirect extrapolation costs of organizations to ensure economic sustainability, RUR;

CД - aggregate income of organizations, RUR;

$$
3 \mathrm{~T}_{\text {эо(п) }}=\frac{\mathrm{P}_{\text {ои }}+\mathrm{P}_{\text {оэп }}+\mathrm{P}_{\text {оэк }}}{\text { СП }},
$$

where $3 \mathrm{~T}_{\text {эо(п) }}$ - the total cost of the stability of the economy of organizations in terms of profit

$\mathrm{P}_{\text {ои }}$ - interpolation costs of organizations to ensure economic sustainability, RUR;

$\mathrm{P}_{\text {оэп }}$ - direct extrapolation costs of organizations to ensure economic sustainability, RUR; RUR;

$\mathrm{P}_{\text {ээ }}$ - indirect extrapolation costs of organizations to ensure economic sustainability,

$\mathrm{C} \Pi_{0}$ - aggregate profit of organizations, RUR.

Now we will form indicators of the intensification of the stability of the economy of organizations, focusing on their essence, which means maximizing the result and minimizing costs in a qualitative way (formulas (5), (6), (7), (8)):

$\Delta \mathrm{CД}_{\text {оэд })}=\left[\frac{\mathrm{CД}_{\text {о1 }}}{\mathrm{P}_{\text {ои1 }}+\mathrm{P}_{\text {оэп1 }}+\mathrm{P}_{\text {оэк1 }}}-\frac{\mathrm{CД}_{\text {о0 }}}{\mathrm{P}_{\text {ои } 0}+\mathrm{P}_{\text {оэп }}+\mathrm{P}_{\text {оэк } 0}}\right] *\left(\mathrm{P}_{\text {ои1 }}+\mathrm{P}_{\text {оэп1 }}+\mathrm{P}_{\text {оэк1 } 1}\right)$,

where $\Delta \mathrm{CД}_{\text {оэл) }}$ - change in total income due to changes in the total performance of the sustainability of the economy of organizations in terms of income, RUR;

$\mathrm{C}_{\mathrm{ol}}$ - reported total income of organizations, RUR;

$\mathrm{P}_{\text {on1 } 1}$ - reporting interpolation costs of organizations to ensure economic sustainability, RUR;

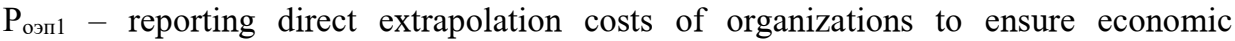
sustainability, RUR;

$\mathrm{P}_{\text {оэк } 1}$ - reporting indirect extrapolation costs of organizations to ensure economic sustainability, RUR;

CД $Д_{00}$ - basic aggregate income of organizations, RUR;

$\mathrm{P}_{\text {он0 }}$ - basic interpolation costs of organizations to ensure economic sustainability, RUR; RUR;

$\mathrm{P}_{\text {оэп }}$ - basic direct extrapolation costs of organizations to ensure economic sustainability,

$\mathrm{P}_{\text {оэк }}$ - basic indirect extrapolation costs of organizations to ensure economic sustainability, RUR;

$\Delta \mathrm{C}_{\text {оэп })}=\left[\frac{\mathrm{C \Pi}_{\text {о1 }}}{\mathrm{P}_{\text {ои1 }}+\mathrm{P}_{\text {оэп1 }}+\mathrm{P}_{\text {оэк1 }}}-\frac{\mathrm{CП}_{\text {о0 }}}{\mathrm{P}_{\text {ои } 0}+\mathrm{P}_{\text {оэп }}+\mathrm{P}_{\text {оэк } 0}}\right] *\left(\mathrm{P}_{\text {ои1 }}+\mathrm{P}_{\text {оэп1 }}+\mathrm{P}_{\text {оэк1 } 1}\right)$,

where $\Delta \mathrm{C} \Pi_{\text {о(эn) }}$ - change in total profit due to changes in the total performance of the sustainability of the economy of organizations in terms of profit, RUR;

$\mathrm{C}_{\mathrm{ol}}$ - reported total profit of organizations, RUR;

$\mathrm{P}_{\text {on1 }}$ - reporting interpolation costs of organizations to ensure economic sustainability, RUR;

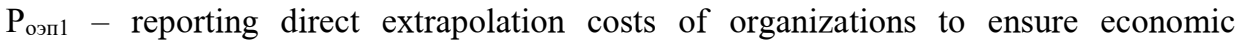
sustainability, RUR;

$\mathrm{P}_{\text {оэк } 1}$ - reporting indirect extrapolation costs of organizations to ensure economic sustainability, RUR;

$\mathrm{C}_{\mathrm{o} 0}$ - basic aggregate profit of organizations, RUR;

$\mathrm{P}_{\text {ои }}$ - basic interpolation costs of organizations to ensure economic sustainability, RUR;

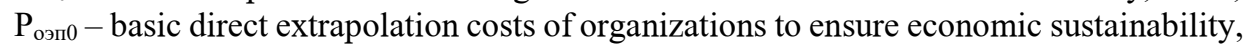
RUR; 
$\mathrm{P}_{\text {оэк }}$ - basic indirect extrapolation costs of organizations to ensure economic sustainability, RUR;

$$
\Delta \mathrm{CP}_{\text {оээ })}=\left[\frac{\mathrm{P}_{\text {ои } 1}+\mathrm{P}_{\text {оэп } 1}+\mathrm{P}_{\text {оэк1 }}}{\text { СДо1 }}-\frac{\mathrm{P}_{\text {оио }}+\mathrm{P}_{\text {оэпо }}+\mathrm{P}_{\text {оэк }}}{\text { СДо0 }}\right] * \mathrm{CД}_{01},
$$

where $\Delta \mathrm{CP}_{\text {оэд) }}$ - change in total costs due to changes in the total cost of stability of the economy of organizations in terms of income, RUR;

$\mathrm{P}_{\text {on1 }}$ - reporting interpolation costs of organizations to ensure economic sustainability, RUR;

$\mathrm{P}_{\text {оэп1 }}$ - reporting direct extrapolation costs of organizations to ensure economic sustainability, RUR;

$\mathrm{P}_{\text {оэк } 1}$ - reporting indirect extrapolation costs of organizations to ensure economic sustainability, RUR;

$\mathrm{CД}_{\mathrm{ol}}$ - reported total income of organizations, RUR;

$\mathrm{P}_{\text {ои0 }}$ - basic interpolation costs of organizations to ensure economic sustainability, RUR;

$\mathrm{P}_{\text {оэп }}$ - basic direct extrapolation costs of organizations to ensure economic sustainability, RUR;

$\mathrm{P}_{\text {оэк }}$ - basic indirect extrapolation costs of organizations to ensure economic sustainability, RUR;

$\mathrm{C}_{00}$ - basic aggregate income of organizations, RUR;

$$
\Delta \mathrm{CP}_{\text {оэп) }}=\left[\frac{\mathrm{P}_{\text {ои } 1}+\mathrm{P}_{\text {оэп1 }}+\mathrm{P}_{\text {оэк1 }}}{\mathrm{CП} 1}-\frac{\mathrm{P}_{\text {ои } 0}+\mathrm{P}_{\text {оэпо }}+\mathrm{P}_{\text {оэк0 }}}{\text { СПо0 }}\right] * \mathrm{C \Pi}_{\text {о1 }},
$$

where $\Delta \mathrm{CP}_{\mathrm{o}(\text { эr) }}$ - change in total costs due to changes in the total cost of stability of the economy of organizations in terms of profit, RUR;

$\mathrm{P}_{\text {ои1 }}$ - reporting interpolation costs of organizations to ensure economic sustainability, RUR;

$\mathrm{P}_{\text {оэп1 }}$ - reporting direct extrapolation costs of organizations to ensure economic sustainability, RUR;

$\mathrm{P}_{\text {оэк } 1}$ - reporting indirect extrapolation costs of organizations to ensure economic sustainability, RUR;

$\mathrm{C}_{\mathrm{ol}}$ - reported total profit of organizations, RUR;

$\mathrm{P}_{\text {ои0 }}$ - basic interpolation costs of organizations to ensure economic sustainability, RUR; RUR

$\mathrm{P}_{\text {оэп } 0}$ - basic direct extrapolation costs of organizations to ensure economic sustainability,

$\mathrm{P}_{\text {оэк } 0}$ - basic indirect extrapolation costs of organizations to ensure economic sustainability, RUR;

$\mathrm{C} \Pi_{00}$ - basic aggregate profit of organizations, RUR.

The indicators formed by the authors fully correspond to the concept of sustainability of the economy of organizations, since the efficiency (profitability and profitability) and cost (expenditure on income and profit) and change in the result (income and profit) and costs (expenses) fully reflect its essence and content as applied to modern conditions inherent in the current economic mechanism.

Explanations of the indicators of stability of the economy of organizations formed by the authors are presented in Table. 1, 2.

Table 1. Interpretation of indicators of the sustainability of the economy of organizations by income

\begin{tabular}{|l|l|}
\hline \multicolumn{1}{|c|}{ Indicator } & \multicolumn{1}{|c|}{ Contents } \\
\hline $\begin{array}{l}\text { Aggregate performance of the } \\
\text { sustainability of the economy of } \\
\text { organizations in terms of income }\end{array}$ & $\begin{array}{l}\text { The total revenues of organizations per unit of the amount } \\
\text { of their expenses in the internal, direct and indirect external } \\
\text { environment }\end{array}$
\end{tabular}


Table 1. Continued

Aggregate cost of the sustainability of the economy of organizations in terms of income

Change in total income due to changes in the total performance of the sustainability of the economy of organizations in terms of income

Change in total costs due to changes in the total cost of stability of the economy of organizations in terms of income
The amount of expenses of organizations in the internal, direct and indirect external environment per unit of their total income

An increase (decrease) in the total income of organizations due to an increase (decrease) in the result (total income) in relation to the amount of their costs in the internal, direct and indirect external environment

Saving (overspending) of organizations' monetary funds due to their increase (decrease) in the amount of costs in the internal, direct and indirect external environment to their result (total revenues)

Table 2. Interpretation of indicators of the sustainability of the economy of organizations in terms of profit

\begin{tabular}{|l|l|}
\hline \multicolumn{1}{|c|}{ Indicator } & \multicolumn{1}{|c|}{ Contents } \\
\hline $\begin{array}{l}\text { Aggregate performance of the } \\
\text { sustainability of the economy of } \\
\text { organizations in terms of profit }\end{array}$ & $\begin{array}{l}\text { The total profit of organizations per unit of the amount of } \\
\text { their expenses in the internal, direct and indirect external } \\
\text { environment }\end{array}$ \\
\hline $\begin{array}{l}\text { The total cost of the sustainability of } \\
\text { the economy of organizations in } \\
\text { terms of profit }\end{array}$ & $\begin{array}{l}\text { The amount of expenses of organizations in the internal, } \\
\text { direct and indirect external environment per unit of their } \\
\text { total profit }\end{array}$ \\
\hline $\begin{array}{l}\text { Change in total profit due to changes } \\
\text { in the total performance of the } \\
\text { sustainability of the economy of } \\
\text { organizations in terms of profit }\end{array}$ & $\begin{array}{l}\text { Increase (decrease) in the total profit of organizations due } \\
\text { to an increase (decrease) in the result (total profit) in relation } \\
\text { to the sum of their costs in the internal, direct and indirect } \\
\text { external environment }\end{array}$ \\
\hline $\begin{array}{l}\text { Change in total costs due to changes } \\
\text { in the total cost of the sustainability } \\
\text { of the economy of organizations in } \\
\text { terms of profit }\end{array}$ & $\begin{array}{l}\text { Saving (overspending) of organizations funds by } \\
\text { increasing (reducing) them the amount of costs in the } \\
\text { internal, direct and indirect external environment to their } \\
\text { result (total profit) }\end{array}$ \\
\hline
\end{tabular}

They show the following advantages of the indicators of the sustainability of the economy of organizations proposed by the authors:

1. Compliance with the elements of the modern environment of functioning, consisting of interpolation and extrapolation factors that affect the efficiency and intensification of economic sustainability.

2. Assistance in accurate calculations of the levels of economic performance and economic cost and the degree of their impact on the result and costs in dynamics and making timely decisions to achieve their best parameters.

Organizations, knowing about these advantages, will receive objective information and apply it to perform the required measures to optimize general and, including interpolation and extrapolation, costs, due to which they will be able to extract the maximum financial benefit and, accordingly, achieve full stability of their economy.

\section{Conclusions}

The indicators of the sustainability of the economy of organizations proposed by the authors are entirely adapted to the conditions of the economic environment, because they are focused on the comprehensive factors of the environment of their functioning in the modern era. They will be able to serve as a reliable tool for them in obtaining complete and accurate information about the efficiency and cost of funds to ensure economic sustainability in general and on interpolation and extrapolation conditions for doing business.

The generated indicators include the entire list of costs in the field of ensuring economic sustainability, represented by the costs of organizations in the internal and external 
environment of their functioning, required to obtain the required amount of profit for expanded reproduction and optimize the result and costs.

Thus, due to the correspondence of the proposed indicators to the prevailing realities in the environment of the functioning of organizations, they are consistent and may be used by them to assess the economic sustainability of the activities carried out to the modern conjuncture, which indicates the achievement of the goal and the solution of problems.

\section{References}

1. O.I. Averina, International Accounting, 41(287), 46 (2013)

2. V. Andreyev, K. Pavlov, Society and economy, 6, 152 (2006)

3. Zh.O. Imashova, Economics and efficiency of production organization, 32, 22 (2020)

4. M.A. Kovtun, O.V. Saradzheva, Economy today: current state and development prospects, 184 (2019)

5. A.S. Krasnikova, Bulletin of the Moscow State Regional University, Series: Economy, 4, 67 (2018)

6. E.A. Laskovskaya, Bulletin of the South Ural State University, Series "Economics and Management, 5(105), 40 (2008)

7. S.N. Nechaeva, V.B. Malitskaya, Bulletin of the Adyghe State University, Economy, 3, 83 (2010)

8. K.V. Pavlov, Economic core. Essence, elemental composition and criteria for its formation, 200 (2009)

9. V.A. Rogova, Russian technological magazine, 6(4), 105 (2018)

10. T.M. Rogulenko, D.A. Pozov, Bulletin of the University, 4, 130 (2015)

11. B.N. Hosiyev, G.Ya. Ostayev, Z.T. Kokoyeva, Accounting in agriculture, 5, 39 (2018) 